\title{
Growth and Transpiration of Jatropha curcas $L$. Seedlings under Natural Atmospheric Vapour Pressure Deficit and Progressive Soil Drying in Semi-Arid Climate
}

\author{
Bassiaka Ouattara ${ }^{1,2 *}$, Ibrahima Diédhiou3 ${ }^{3}$, Nouhoun Belko1,4, Ndiaga Cissé1 \\ ${ }^{1}$ Centre d'Etude Régional pour l'Amélioration de l'Adaptation à la Sécheresse (CERAAS), Thiès, Sénégal \\ ${ }^{2}$ Université de Fada N'Gourma (U-FDG), Fada N'Gourma, Burkina Faso \\ ${ }^{3}$ Département de Productions Végétales, Ecole Nationale Supérieure d’Agriculture (ENSA), Université de Thiès, Thiès, Sénégal \\ ${ }^{4}$ International Institute of Tropical Agriculture (IITA), Kano, Nigeria \\ Email: *bass.ouatt@gmail.com
}

How to cite this paper: Ouattara, B., Diédhiou, I., Belko, N. and Cissé, N. (2018) Growth and Transpiration of Jatropha curcas L. Seedlings under Natural Atmospheric Vapour Pressure Deficit and Progressive Soil Drying in Semi-Arid Climate. Agricultural Sciences, 9, 639-654.

https://doi.org/10.4236/as.2018.96044

Received: February 14, 2018

Accepted: June 11, 2018

Published: June 14, 2018

Copyright $\odot 2018$ by authors and Scientific Research Publishing Inc. This work is licensed under the Creative Commons Attribution International License (CC BY 4.0).

http://creativecommons.org/licenses/by/4.0/

c. $\underset{\mathrm{EY}}{\mathrm{C}}$ Open Access

\begin{abstract}
During the last decade, Jatropha curcas L. (J. curcas) has gained much attention worldwide as biofuel crop. Although its cultivation is promoted in the Sahel, there is a surprising lack of data on its water use regulation and growth in this region. Here, we investigated, in semi-controlled conditions, leaf transpiration and growth of six accessions of $J$. curcas at seedling stage under natural changing in vapour pressure deficit (VPD) and progressive soil drying in Senegal. The experimental layout was a randomized complete bloc design and after 3 months of growth arranged to a split-plot at the implementation of water stress to facilitate irrigation. Under well water condition, there was no significant difference between accessions for leave transpiration that was positively correlated to VPD with high values recorded between $13 \mathrm{~h}$ and $14 \mathrm{~h} \mathrm{pm}$. Accessions of $J$. curcas used in this study showed closed thresholds at which transpiration declined except accession from Ndawene that threshold was lower (0.30). There is no significant difference between accessions for growth during the experimentation period. In 3 months, we recorded $23.57 \mathrm{~g}$ for the aboveground dry biomass and seedlings had about 14 leaves and $24.3 \mathrm{~cm}$ height. Positive linear correlation was recorded between aboveground biomass and root dry weight $(\mathrm{p}<0.0001)$ and between total biomass and collar diameter $(\mathrm{p}<0.0001)$ as well as between leaf area and leaf dry weight $(\mathrm{p}<$ 0.0001). In natural climatic conditions in Sahel zone, cultivation of J. curcas might need complement irrigation for a better growth of seedlings especially during the dry season.
\end{abstract}




\section{Keywords}

Growth, Jatropha curcas L., Leaf Transpiration, Water Stress, Senegal

\section{Introduction}

Jatropha curcas (J. curcas), an oil-seed shrub of Euphorbiaceae family, has been identified as an important source of biodiesel [1]. Its seed is rich in oil (35\%) that is non-edible and can be refined under normal atmospheric temperature and pressure conditions [2]. Moreover, J. curcas is not browsed by animals because of its toxicity and could grow in semi-arid regions with low nutrient requirements and little care [3]. Its cultivation has a good potential to rehabilitate degraded wastelands by greening them while providing employment to the rural poor and meeting rural energy demands [4]. All these make J. curcas an excellent potential candidate for biodiesel production. It is now planted worldwide on wastelands in the semi-arid tropics [5] [6].

In many countries of West Africa, cultivation of J. curcas, presented as a potential source of biodiesel and accessible energy for rural populations, is encouraged. The government of Senegal launched in 2007 the national program for biofuel entitled "Programme National Biocarburant" [7]. However, to avoid competition with food crops, its cultivation is expected to be done on marginal soils with low rainfall and poor fertility as the species is presented to be able to grow on poor degraded soil [8]. Despite of this characteristic to grow on degraded soil and its reputation of being a drought-resistant and easily establishing species, the water-relationship of J. curcas in Sahelian zone needs to be well documented. The experiences in J. curcas cultivation in Sahel zone are mainly limited in live fence experiences and little is known on the agronomic data based on large scale cultivation. This region is characterized by a hot climate and limited rainfall estimated on the order of 100 to $200 \mathrm{~mm}$ per year in the North-Sahel where cultivation of J. curcas is expected to be done [9]. There is a strong variation in rainfall and temperature and the rainy season length does not exceed 2 months in this climatic area.

Due to limited rainfall and hot temperature in Sahelien zone where J. curcas cultivation is planed and the fact that assimilation of carbon by plant incurs water costs [10] one of the questions is how J. curcas could manage water loss by transpiration in this condition and how the transpiration varies across different J. curcas accessions. The response to these two questions could help to develop appropriate management interventions by promoting its wide-scale cultivation. It could also help in identifying genotypes presenting a best management of water and could provide important information to plant breeders. Investigation on plant-water relationship of $J$. curcas under drought and artificial conditions $\left(\mathrm{CO}_{2}\right.$ enhanced, irrigation with nutrients water) has been reported [11]. The conditions of areas where cultivation of $J$. curcas is planed are far to these ideal 
conditions. So, we investigated leaf transpiration and growth under semi-controlled conditions of Sahelian zone in dry season. In this study, our aims were to 1) determine diurnal pattern of $J$. curcas seedling transpiration under natural changing in VPD in sahelian zone, 2) investigate the transpiration response of different accessions of $J$. curcas accessions to a progressive soil dry-down and 3) seedling early growth.

\section{Material and Methods}

\subsection{Plant Material and Growing Conditions}

The experiment was conducted at the outdoor conditions at the Regional Research Centre for the Improvement of Crop Adaptation to Drought (Ceraas). Six accessions selected from the J. curcas collection of ENSA (Ecole Nationale Supérieure d'Agriculture) were used based on seeds weight and rainfall of origins in order to have accessions with contrasted seeds weight and contrasted rainfall considering the collection sites in Senegal (Table 1).

Plastic Pots with $20 \mathrm{~cm}$ height, $21 \mathrm{~cm}$ in diameter and a volume of $5 \mathrm{~L}$ were used for the experimentation. The pots were filled with $8 \mathrm{~kg}$ of soil to a $16.5 \mathrm{~cm}$ height. The soil used was of Ferra-sols type, composed of sand (91\% - 95\%) and clay $(3.5 \%-5.6 \%)$, with low organic matter $(0.27 \%-0.34 \%)$, low nitrogen $(0.16 \%-0.19 \%)$, and low $\mathrm{pH}(6-6.5)$.

Pots with dry soil were weighted (DW) before saturating with water and allow draining freely until there was no water lost by draining and pots were weighted again (SW). So, water holding capacity (WHC) of soil in the pot was determined as.

$$
\mathrm{WHC}=\mathrm{DW}-\mathrm{SW}
$$

where WHC is water holding capacity, DW is the weight of the pot with dry soil and SW the weight of the pot when saturated with water.

A total of 126 pots were used (21 pots for each of the six accessions). Distance between pots and between lines was $0.5 \mathrm{~m}$. Three seeds were directly sown per

Table 1. Seeds characteristics of the six accessions of $J$. curcas and rainfall of collection sites.

\begin{tabular}{cccccc}
\hline \multicolumn{7}{c}{$\begin{array}{c}\text { Rainfall of } \\
\text { Accession } \\
\text { origin (Bourou, } \\
\text { 2012) }[12]\end{array}$} & $\begin{array}{c}100 \text { Seed-weight } \\
(\mathrm{g})\end{array}$ & $\begin{array}{c}\text { Length }(\mathrm{mm}) \\
\text { Ndawene }\end{array}$ & $500-900 \mathrm{~mm}$ & $65.06 \pm 1.64$ & $17.68 \pm 0.11$ & $10.86 \pm 0.06$ & $8.32 \pm 0.07$ \\
Mako Foukola & $900-1100 \mathrm{~mm}$ & $72.76 \pm 0.75$ & $18.63 \pm 0.03$ & $11.02 \pm 0.01$ & $8.46 \pm 0.02$ \\
Barkeyel & $500-900 \mathrm{~mm}$ & $71.94 \pm 0.65$ & $18.38 \pm 0.02$ & $11.13 \pm 0.01$ & $8.63 \pm 0.02$ \\
Bantancountou & $900-1100 \mathrm{~mm}$ & $74.09 \pm 0.80$ & $18.86 \pm 0.01$ & $11.02 \pm 0.01$ & $8.66 \pm 0.03$ \\
Latmingue & $500-900 \mathrm{~mm}$ & $58.89 \pm 0.48$ & $17.87 \pm 0.05$ & $11.09 \pm 0.03$ & $8.55 \pm 0.01$ \\
Mampatim & $900-1100 \mathrm{~mm}$ & $77.83 \pm 0.20$ & $19.02 \pm 0.04$ & $11.36 \pm 0.01$ & $8.91 \pm 0.01$ \\
\hline
\end{tabular}


pot. Two weeks after sowing, seedlings were thinned to one plant per pot. To monitor temperature and humidity, a Thermo-hygrometer (Hobo ${ }^{\circ}$ Pro Series Temp H08-032-08, RH ( 1998 ONSET) has been programmed and suspended in the experimental site to record temperature and humidity at each ten minutes. All the plants were kept at $90 \%$ WHC by manual irrigation and allow to grow until 3 months in a random complete design (Figure 1).

\subsection{Preparation of Pots and Measurement of Seedling Transpiration under Natural VPD}

The day before the beginning of transpiration measurements ( 3 months after sowing), 90 uniform seedlings (15 seedlings per accession) were chosen and water saturated and allow to drain freely overnight. Thereafter, early on the next day, all the 90 pots were bagged in a transparent plastic bag wrapped around the base of plant stem to prevent soil evaporation [13]. Afterward, transpiration of 30 uniform seedlings (5 seedlings per accession) was measured outdoor along of two entire sunny days by weighting pots each hour. Plant transpiration was measured gravimetrically and corresponded to the losses in pot weight between consecutive weightings. So, to determine hourly seedling transpiration, pots were weighted hourly between $07 \mathrm{~h} 30$ and 18 h 30 on an electronic scale (OHAUS EB15, $15 \mathrm{~kg} / 0.5 \mathrm{~g}$, USA). Hourly seedling transpiration was calculated as the difference between two consecutives weighting.

Evaporative demand was estimated by calculating vapour pressure deficit (VPD) each 10 minutes along the day of measurement according to [14].

$$
\mathrm{VPD}=(1-\mathrm{RH} / 100) * \mathrm{SVP}
$$

where RH is relative humidity and SVP is saturated vapour pressure

$$
\operatorname{SVP}(\text { Pascals })=610.7 * 10^{7.5 T /(237.3+\mathrm{T})}
$$

$\mathrm{T}$ is the air temperature $\left({ }^{\circ} \mathrm{C}\right)$.

\subsection{Harvest and Determination of Leaves Areas and Seedlings Biomass}

The day following the two days of the measurement of seedling transpiration

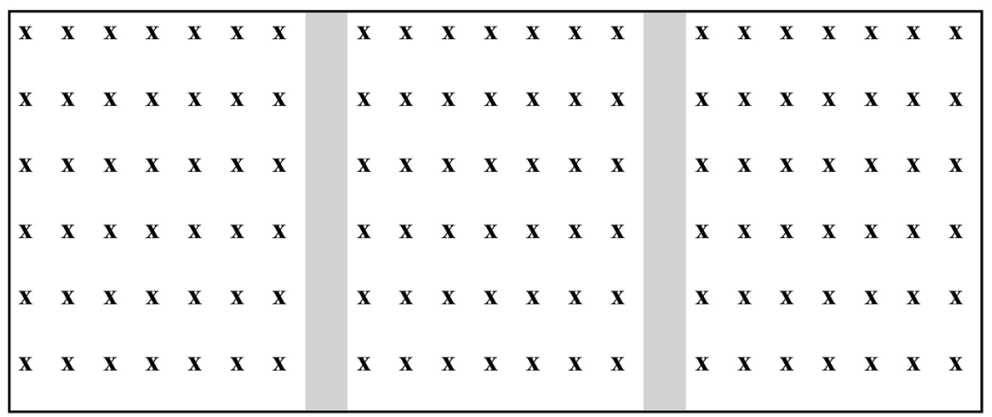

Figure 1. Experimental design before applying water stress treatment. Each column represents six accessions randomized; each $\mathrm{X}$ represents a pot. 
under natural VPD, the corresponding 30 seedlings used (5 per accession) were harvested and leaf area of each seedling was measured through a scanner (EPSON expression 10000XL, model J181A) using WinRhizo pro V2008b application to determine leaves area. Due to variation of leaf area from seedling to seedling, transpiration was computed as water loss per unit of leaf area and called transpiration rate (TR). Rooting observations revealed that the plants had fully explored the pot soil volume. Thus, all the transpirable soil water content was accessible to the plants. Dry weight of leaves was determined after oven-drying $\left(70^{\circ} \mathrm{C}\right)$ until constant weight $(72 \mathrm{~h})$. Specific leaf area (SLA) was calculated as the ratio between the leaf area and the corresponding dry weight.

\subsection{Transpiration Response to Progressive Drought}

The remaining 60 seedlings (10 per accession) were arranged in a split-plot layout. Water stress was the main factor and accessions the secondary factor in order to facilitate pots irrigation (Figure 2). The water regime included two modalities; well watered and water stressed and the secondary factor included six modalities (6 accessions). The well watered pots included five seedlings of each accession that were irrigated daily (in the morning) to maintain $90 \%$ of WHC (Water Holding Capacity) during all the treatment phase and corresponding to well watered seedling. The water stressed seedlings including also five seedlings of each accession that were exposed to progressive water deficit. In fact, when seedlings loss more than $200 \mathrm{~g}$ of water the day, the excess to the $200 \mathrm{~g}$ were added back to the pots the next day, as previously described by [15]. So, all the genotypes were exposed to similar stress intensities, at least from the viewpoint of the soil water content. This aims to have a progressive dry in the pots in order to determine at which moment water stress affects plant transpiration. So, seedlings were let to grow and submitted to progressive dry at outdoor

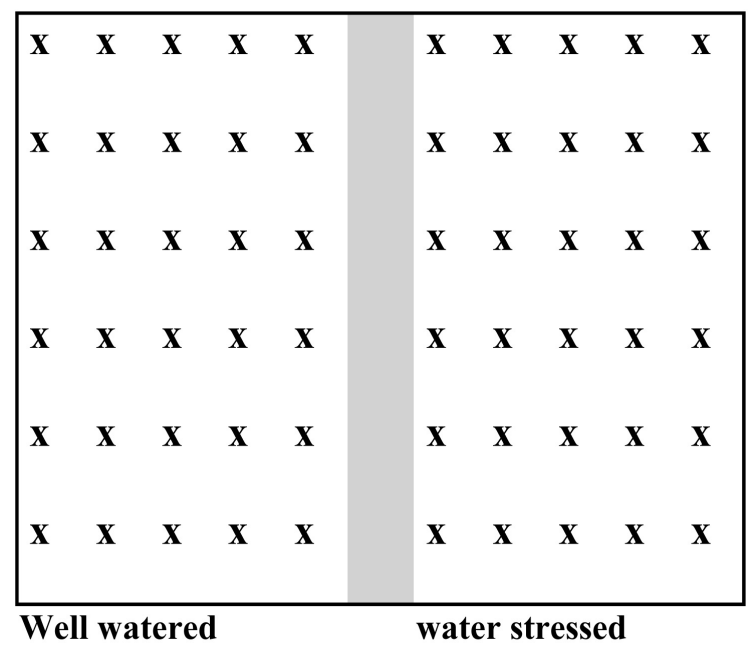

Figure 2. Experimental design at water stress application. Each column represents six randomized seedlings (1 per accessions), each $\mathrm{X}$ represents a pot. 
conditions. Throughout the experiment, pots were weighted daily during 3 weeks at $9 \mathrm{~h}$ am to calculate seedling transpiration and soil water content.

The daily transpiration ( $\mathrm{Tr}$ ) was calculated based on the weights before and after watering and corrected for water added back following the equation:

$$
\operatorname{Tr}=\text { Weight }_{\mathrm{n}-1}-\text { Weight }_{\mathrm{n}}+\text { WaterAdded }_{\mathrm{n}-1}
$$

Weight $_{\mathrm{n}-1}$, Pot weight at day $\mathrm{n}-1$; Weight ${ }_{n}$, Pot weight at day n; WaterAd$\operatorname{ded}_{n-1}$, quantity of water added in the pot at day $n-1$ when transpiration exceeded $200 \mathrm{~g}$.

The daily transpiration ( $\operatorname{Tr}$ ) values were normalized twice to facilitate comparison between seedlings. First, to minimize day to day variation resulting from changes in evaporative demand, values of daily transpiration of the individual stressed plants were expressed relative to the mean of the control seedlings (well-watered seedlings of the same accession), yielding daily transpiration ratio (DTR).

$$
\mathrm{DTR}=\operatorname{Tr}_{\text {stressed }} / \operatorname{Tr}_{\text {watered }}
$$

$\mathrm{Tr}_{\text {stressed }}$ corresponds to the daily transpiration of individual stressed seedling. $\mathrm{Tr}_{\text {watered }}$ corresponds to the mean of daily transpiration of the 5 well watered seedlings belonging to the same accession with the stressed one.

The daily transpiration ratio (DTR) of each seedling was normalized by dividing each DTR value over time by the average of the DTR value of the seedling recorded in the first 3 days of measurements when there were still no water limitation effects. This second normalization gave the normalized transpiration ratio (NTR), which accounted for seedling to seedling variation in transpiration within the same accession and determined as:

$$
\mathrm{NTR}=\mathrm{DTR}_{\mathrm{n}} / \mathrm{DTR}_{3 \text { dayMean }}
$$

$\mathrm{DTR}_{\mathrm{n}}$, Daily Transpiration Ratio of day n; DTR $\mathrm{DdayMean}_{\text {; }}$ mean of Daily Transpiration Ratio of the first 3 days of measurement.

\subsection{Monitoring of the Soil Water Status}

The soil water status was monitored using the fraction of transpirable soil water (FTSW) as recommended by [16]. The FTSW values representing the portion of remaining volumetric soil water available for seedling transpiration on each day of the experiment were used as the indicator of water stress [17]. Total transpirable soil water (TTSW) was calculated as the difference of pot weight at water holding capacity (before exposure to dry down) and pot weight when transpiration rate of the stressed plants was negligible (about $10 \%$ of the control). It represents approximately the amount of water that can be extracted to support seedling transpiration from the soil. The experiment ended when the transpiration rates were lower than $10 \%$ of the well watered seedling transpiration of the same accession as recommended by [18]. The daily value of FTSW was estimated as the ratio between the amount of transpirable soil water still remaining 
in the pot and TTSW [19] as followed:

$$
\begin{gathered}
\mathrm{FTSW}=\left(\mathrm{WT}_{\mathrm{n}}-\mathrm{WT}_{\mathrm{f}}\right) / \mathrm{TTSW} \\
\text { TTSW }=\mathrm{WT}_{\mathrm{s}}-\mathrm{WT}_{\mathrm{f}}
\end{gathered}
$$

where $\mathrm{WT}_{\mathrm{n}}$ is the pot weight on a given date $\mathrm{n}, \mathrm{WT}_{\mathrm{s}}$ pot weight at water saturation (before applying water stress) and $\mathrm{WT}_{\mathrm{f}}$ the pot weight at the end of experimentation when transpiration rate of stressed plants was lower than $10 \%$ of the control, TTSW is the total transpirable soil water.

\subsection{Statistical Analysis}

A one way Analysis of variance (ANOVA), with accession as factor, was performed for each investigated parameters before water stress imposition (randomized bloc design with 6 accession); using $\mathrm{R}$ software. When significant effect was recorded $(\mathrm{P} \leq 0.05)$, the test of Tukey's honestly significant differences was used for the comparison and grouping of means. When pots were arranged in split-plot during the water stress imposition, only the computed FTSW were used for analysis to compare accessions. FTSW thresholds where NTR initiates its decline were computed with SAS software using a plateau regression procedure as described by [20]. In each regression, a standard error (S.E.) and confidence interval were associated with the estimated FTSW threshold.

\section{Results}

\subsection{Leaf Transpiration Response to Vapor Pressure Deficit (VPD)}

Variation in TR was closely linked to natural changing of VPD as illustrated in Figure 3. TR started with low values at sunrise corresponding to low values of

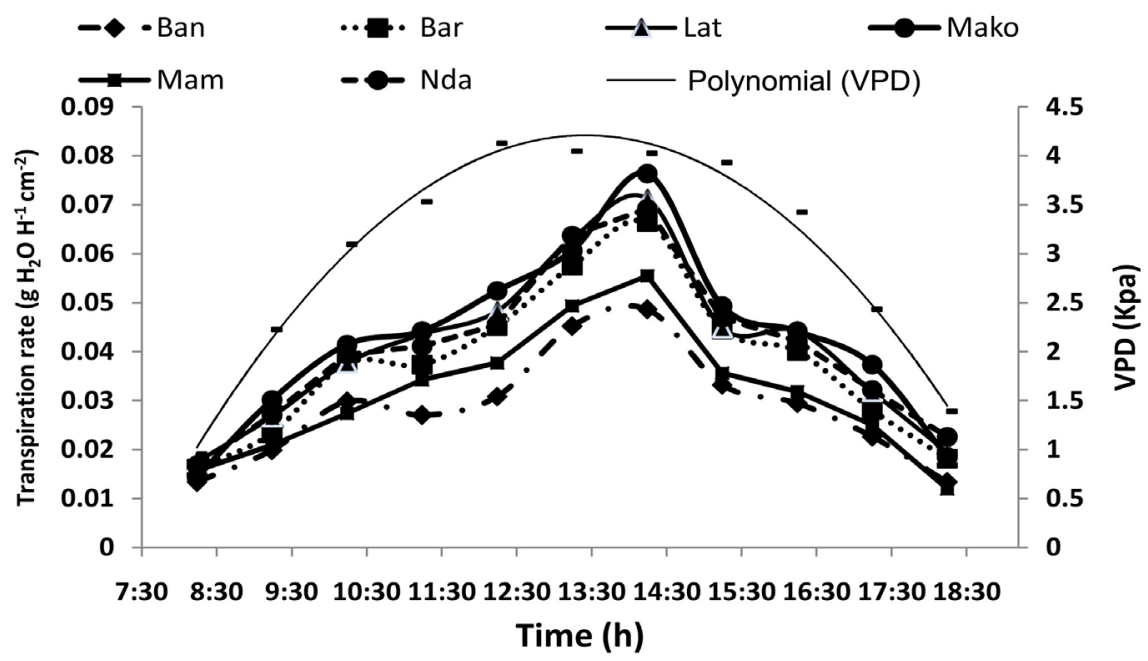

Figure 3. Relationship between J. curcas seedlings transpirationand VPD as measured on 3 months after sowing. Ban: accession of Bantancountou; Bar: accession of Barkeyel; Lat: accession of Latmingue; Mako: accession of MakoFoukola; Mam: accession of Mampatim; Nda: accession of Ndawene; VPD: Vapour pressure deficit; Poly. (VPD): polynomial function adjusting VPD data. 
VPD and reached its maximum when VPD values were at its maximum between 12:30 and 14:30 (GMT). After that, TR declined progressively. The TR for all the accessions were closed at sunrise and at sunset while largest variation was recorded at high values of VPD. The highest value of TR $\left(76.4 \mathrm{mg} \cdot \mathrm{cm}^{-2} \cdot \mathrm{h}^{-1}\right.$ corresponding to $11.78 \mathrm{mmol} \cdot \mathrm{m}^{-2} \cdot \mathrm{s}^{-1}$ ) was recorded in Mako Foukola accession whereas the lowest $\left(48.65 \mathrm{mg} \cdot \mathrm{cm}^{-2} \cdot \mathrm{h}^{-1}\right.$ corresponding to $\left.7.51 \mathrm{mmol} \cdot \mathrm{m}^{-2} \cdot \mathrm{s}^{-1}\right)$ was recorded in Bantancountou Accession. However, no significant difference of the accessions for Transpiration rate (TR) was recorded according to the Anova test $(\mathrm{P}>0.05)$ considering the different periods of the day.

The accessions with high Transpiration rates recorded the higher total water transpired per plant throughout the day (Figure 4).

\subsection{Transpiration Rate under the Progressive Soil Drying Stress}

No rain was recorded during the experimentation. Figure 5 summarizes the temperatures and the relative humidity that occurred during the water stress implementation.

Five of the six accessions didn't present a significant difference for their fraction transpirable soil water (FTSW) threshold according to the Anova test $(\mathrm{P}>$ 0.05 ) as represented in Table 2. Only transpiration of Ndawene was significantly low (0.30). The decline in NTR was linked to the gradual depletion of soil moisture content. Variation in NTR as a function of FTSW was well represented by the equation of [21] (Figure 6). The FTSW threshold was reached after 8 days of progressive soil drying (loss of $200 \mathrm{~g}$ per day) this represents about $56.07 \%$ of TTSW. At the end of experiment, stomata conductance could not be measured longer since seedling experienced a severe water shortage.

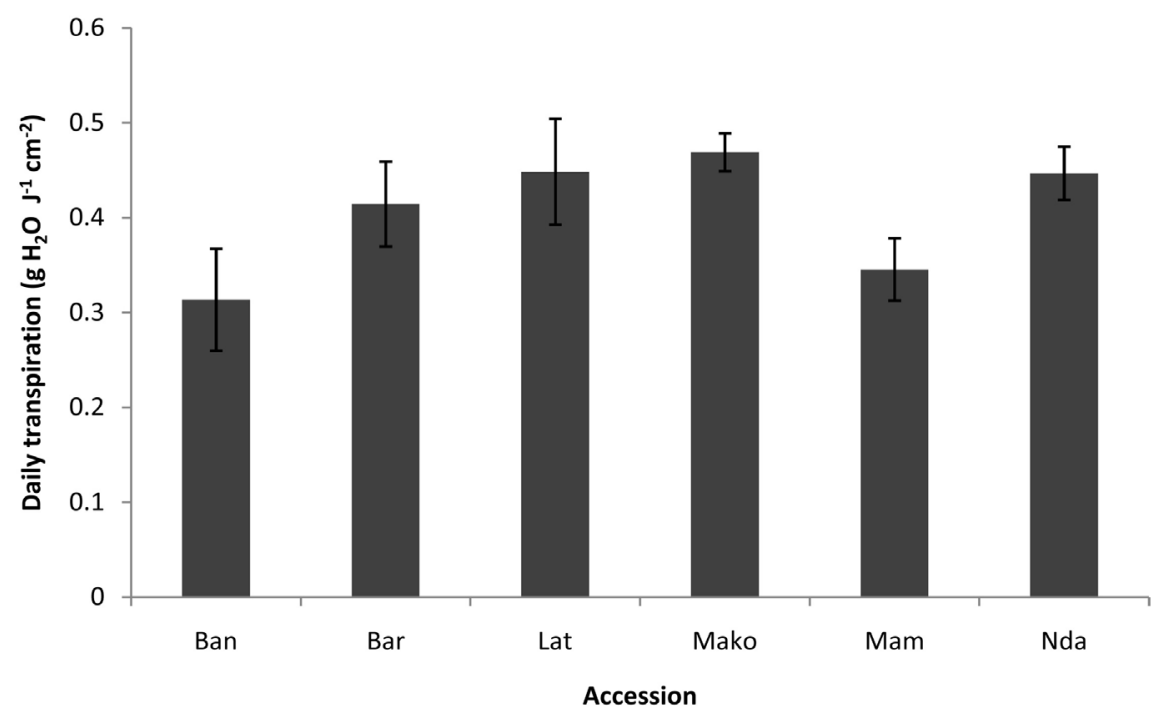

Figure 4. Total water transpired per plant throughout the day as measured 3 months after sowing. Ban: accession of Bantancountou; Bar: accession of Barkeyel; Lat: accession of Latmingue; Mako: accession of MakoFoukola; Mam: accession of Mampatim; Nda: accession of Ndawene. Error bars represent the standard errors. 


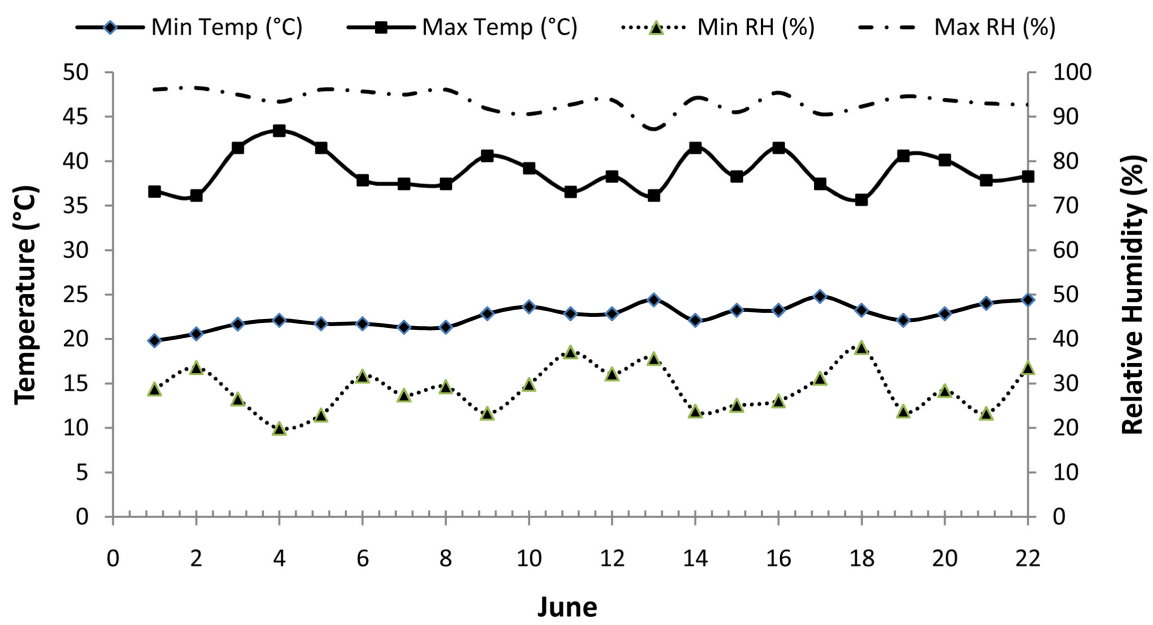

Figure 5. Overview on temperatures and the relative humidity during the water stress implementation.
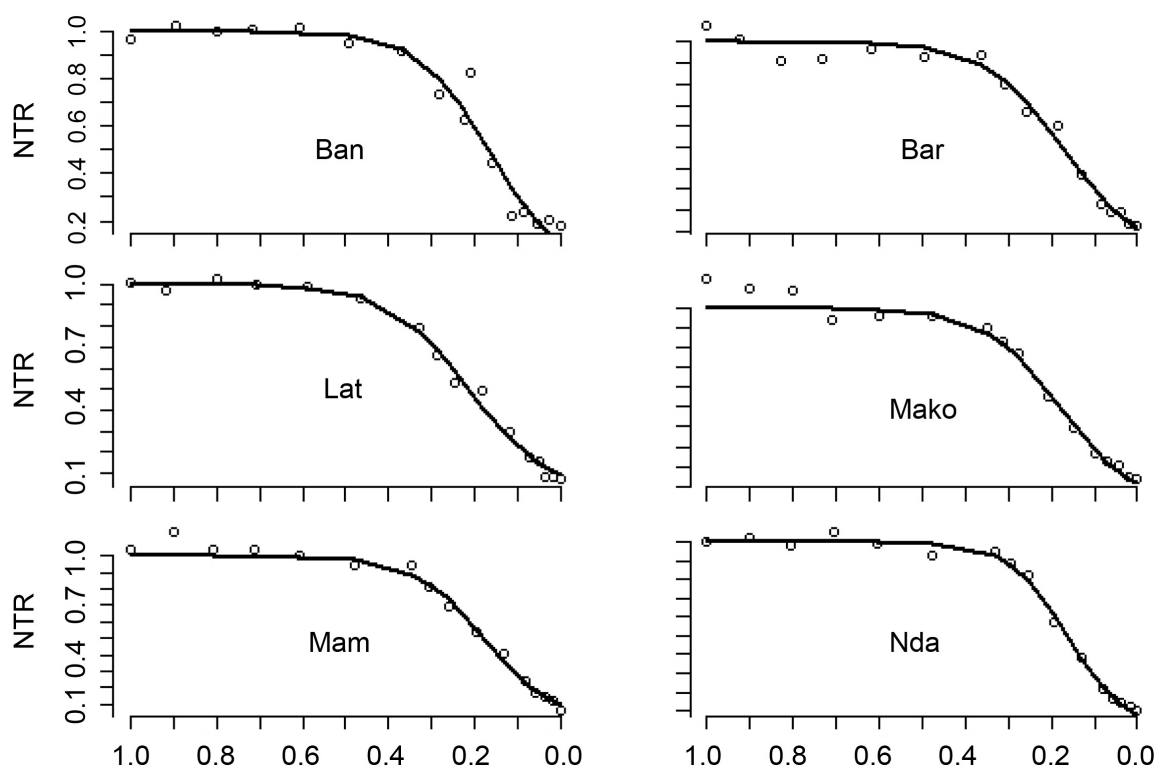

Figure 6. Normalized transpiration rate (NTR) of J. curcas seedlings (data are mean of 5 seedlings) as a function of fraction transpirable soil water (FTSW).

Table 2. FTSW threshold of the six accessions of J. curcas at which normalized transpiration ratio dropped.

\begin{tabular}{cccc}
\hline Accession & FTSW Threshold & Standard Error & Approximate 95\% IC \\
\hline Bantancountou & $0.3893 \mathrm{a}$ & 0.0276 & $0.3301-0.4485$ \\
Barkeyel & $0.3916 \mathrm{a}$ & 0.0166 & $0.3561-0.4271$ \\
Latmingué & $0.4362 \mathrm{a}$ & 0.0134 & $0.4076-0.4649$ \\
MakoFoukola & $0.3907 \mathrm{a}$ & 0.019 & $0.3500-0.4313$ \\
Mampatim & $0.3753 \mathrm{a}$ & 0.0134 & $0.3466-0.4041$ \\
Ndawène & $0.3021 \mathrm{~b}$ & 0.0128 & $0.2746-0.3295$ \\
\hline
\end{tabular}

Value with the same letter are not statistically different; IC, confidence interval. 


\subsection{Seedling Growth during the First 3 Months}

Seedlings growth in the six accessions was similar during the first three months of sowing (Table 3). Significant linear correlation between certain growth parameters using Pearson correlation test was recorded (Table 4). Positive linear correlation was recorded between aboveground biomass and root dry weight and between total biomass and collar diameter. Highest Pearson correlation coefficient (0.99) was recorded between leaf area and leaf dry weight. Significant linear regressions were found between leaf surface and leaf dry biomass (Figure 7).

\section{Discussion}

\subsection{Transpiration Rate (TR) Response to Natural Variation of Vapour Pressure Deficit (VPD)}

Transpiration rate (TR) followed the pattern of natural VPD variation throughout the day. This might be explained by an adjustment of stomatal response of $J$. curcas seedling in relation to change in VPD as it has been reported in Acacia tortilis [22]. Therefore, because of differences in VPD of seasons and agro-ecological zones, transpiration rate of $J$. curcas could be different according to the seasons and the agro-ecological zones. The transpiration rate recorded in this study is on the order of those recorded by [23] in China on Agropyron

Table 3. Growth parameters of J. curcas seedlings recorded three months after sowing in well watered condition.

\begin{tabular}{|c|c|c|c|c|c|c|}
\hline \multirow{2}{*}{ Parameters } & \multicolumn{6}{|c|}{ Accession } \\
\hline & Ban & Bar & Lat & Mako & Mam & $\mathrm{Nda}$ \\
\hline $\begin{array}{l}\text { Aboveground } \\
\text { DW (g) }\end{array}$ & $18.64 \pm 1.28$ & $22.34 \pm 3.25$ & $25.97 \pm 2.85$ & $25.26 \pm 4.20$ & $24.79 \pm 3.09$ & $24.55 \pm 1.24$ \\
\hline Collar D (mm) & $16.24 \pm 0.32$ & $18.26 \pm 1.18$ & $19.89 \pm 0.68$ & $19.18 \pm 1.68$ & $18.55 \pm 0.88$ & $18.82 \pm 0.44$ \\
\hline $\mathrm{LA}\left(\mathrm{cm}^{2}\right)$ & $512.01 \pm 40.72$ & $616.56 \pm 104.12$ & $712.30 \pm 139.46$ & $816.84 \pm 129.73$ & $638.10 \pm 92.92$ & $753.83 \pm 58.90$ \\
\hline $\begin{array}{c}\text { Number of } \\
\text { leave }\end{array}$ & $12.00 \pm 0.54$ & $12.80 \pm 1.15$ & $15.60 \pm 1.28$ & $14.20 \pm 1.31$ & $13.40 \pm 1.36$ & $14.40 \pm 0.67$ \\
\hline Height $(\mathrm{cm})$ & $23.20 \pm 0.33$ & $22.30 \pm 1.07$ & $24.50 \pm 2.01$ & $25.90 \pm 1.56$ & $23.80 \pm 1.79$ & $26.10 \pm 1.00$ \\
\hline Root DW (g) & $2.82 \pm 0.20$ & $3.30 \pm 0.59$ & $4.01 \pm 0.30$ & $3.25 \pm 0.57$ & $3.55 \pm 0.34$ & $3.02 \pm 0.34$ \\
\hline SLA $\left(\mathrm{cm}^{2} \cdot \mathrm{g}^{-1}\right)$ & $110.65 \pm 2.84$ & $104.03 \pm 0.47$ & $108.50 \pm 2.77$ & $112.30 \pm 1.52$ & $110.09 \pm 1.97$ & $109.51 \pm 1.09$ \\
\hline
\end{tabular}

Ban: accession of Bantancountou; Bar: accession of Barkeyel; Lat: accession of Latmingue; Mako: accession of MakoFoukola; Mam: accession of Mampatim; Nda: accession of Ndawene. DW: dry weight; collar D: collar diameter; LA: leaf area; SLA: specific leaf area.

Table 4. Pearson correlation coefficient between seedling growth parameters.

\begin{tabular}{cccc}
\hline & Dcollar & LeafArea & LeafDw \\
\hline Leaf Area & $0.6852(0.0000)$ & & \\
Leaf dry weight & $0.6794(0.0000)$ & $0.9862(0.0000)$ & $0.6674(0.0001)$ \\
Root dry weight & $0.7255(0.0000)$ & $0.6495(0.0001)$ & $0.7720(0.0000)$ \\
Aboveground biomass & $0.8199(0.0000)$ & $0.7718(0.0000)$ & $0.8888(0.0000)$ \\
\hline
\end{tabular}

Values in bracket are the probabilities of Pearson test. Dcollar, collar diameter; LeafDW, leaf dry weight; RootDw, root dry weight. 


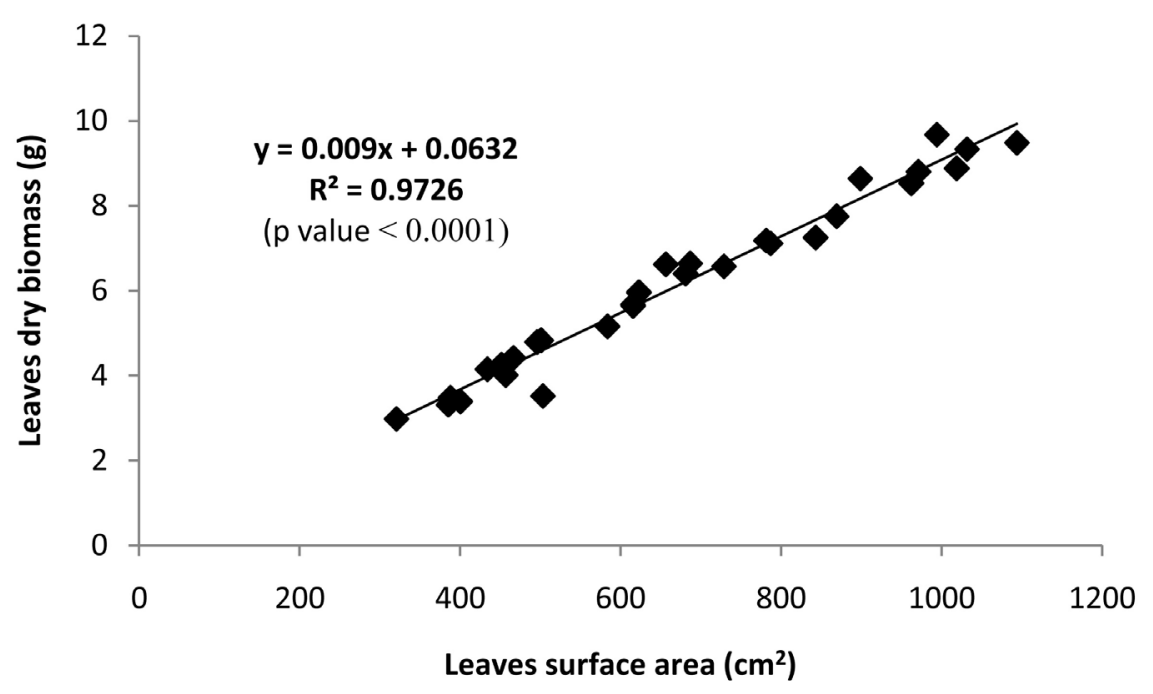

Figure 7. Leaves dry biomass as a function of leaves surface area of 6 accessions of J. curcas cultivated under well water conditions.

cristatum (11.99 $\mathrm{mmol} \mathrm{H}_{2} \mathrm{O} \mathrm{m}^{-2} \mathrm{~s}^{-1}$ ) and Cleistogenes squarrosa (10.31 $\mathrm{mmol}$ $\left.\mathrm{H}_{2} \mathrm{O} \mathrm{m}^{-2} \mathrm{~s}^{-1}\right)$, and on Acacia tortilis in Senegal $\left(8 \mathrm{mmol} \cdot \mathrm{m}^{-2} \cdot \mathrm{s}^{-1}\right)$ as revealed by [24]. Therefore, gravimetric method used in this study appeared to be adequate for transpiration measurement and gave comparables values to those of porometers used in these previous studies.

No difference was observed between the accessions for TR despite of the different noted in rainfall of the collection sites. So, the distribution of $J$. curcas throughout the country is not based on differences strategies in water use at seedling stage under well watered conditions regardless to the time of the day. This might be explained by the vegetative propagation of $J$. curcas, mainly via exchange of cuttings, across the country as described by [25]. [12] also didn't record any differences in eco-physiological parameters in accessions of Tamarindus indica originated from different agro-ecological zones in Senegal.

Under well watered conditions, water loss by J. curcas is positively correlated to VPD as reported by [26]. However, under artificial conditions [11] recorded reduction of leaves transpiration of $J$. curcas when VPD reaches about $3.2 \mathrm{KPa}$.

In Sahel area, because of high VPD, cultivation in large scale of J. curcas will probably cause a high water loss from soil via transpiration especially during the wet season where water is available for J. curcas plants that present at this period high leaves surface. High evapo-transpiration of $J$. curcas, under increased atmospheric demand and non-water limited conditions, has been reported [2].

\subsection{Effects of Accession on the Transpiration Rate under Progressive Soil Drying Conditions}

Accessions of $J$. curcas used in this study showed closed thresholds at which transpiration declined except accession from Ndawene. The stomata control of leaves transpiration in response to water depletion in the soil didn't vary much 
between the accessions. This might be explained by a low genetic differentiation between accessions as J. curcas is spread mainly by cutting in Senegal [25]. Little variations in morpho-physiological parameters have also been reported in others studies in Senegal [27]. However, there exists a low genetic diversity as reported by [28]. It is known that difference in genes (in the nucleotide sequences) or because of the methylation of DNA as reported by [29] could explain differences in organism's behaviors.

Considering the concordance of transpiration of $J$. curcas accessions originated of different rainfall conditions in our study (Table 1), we can conclude that $J$. curcas seedling transpiration behavior is not necessary linked to the rainfall of its origins. The distribution of J. curcas in Senegal is not necessary linked to different strategies in water used but might explained by its high adaptability to large scale of climatic and soil conditions as reported in by [30].

This is inconsistent to results of [31] who reported that ecotypes of Populus davidiana originated from dry zone have a conservative water use than those collected from wet zone. J. curcas is spread across the country mainly by cutting and populations of $J$. curcas in Senegal are not natural. According to [27] local populations of $J$. curcas in Senegal are live fences or isolated tree planted mainly by cuttings. Cuttings are shared between parents and relative. This might explain the lack of difference between accessions collected in different sites.

Seedlings of $J$. curcas reduce their transpiration rate only when the fraction of transpirable soil water (FTSW) fell below 0.5. This strategy allows J. curcas seedling to grow under climate with low to moderate soil moisture. This characteristic is an advantage for $J$. curcas seedlings in low to moderate rainfall zones. The mean FTSW threshold at which transpiration dropped was 0.39. Therefore, we can say that irrigation at about $50 \%$ field capacity seems to be sufficient to ensure growth of J. curcas seedlings. [2] highlighted that $J$. curcas seed yield is more affected by the repartition of rainfall through the rainy season by it quantity.

The declining of transpiration at FTSW threshold (0.39) indicated that physiological parameters of $J$. curcas seedling are affected by a severe water stress. These results corroborate the fact that under severe water stress conditions, transpiration rate of $J$. curcas seedlings is not correlated to the increase of its leaves surface area as reported by [11]. The adjustment of leave transpiration in relation to FTSW is a physiological characteristic revealed in many species [13] [20]. Indeed, the control of water loss by reducing transpiration rate is a mechanism that allows species, especially from dry zones, to cope with water stress [32]. By reducing its transpiration under water stress condition, plant avoids death and keeps minimum water for tissues metabolism reaction. Decrease in eco-physiological parameters values under water stress has been reported in many studies [12] [13]. However, the FTSW threshold at which they decline are function of the substratum making difficult to do a comparison between species basing in data revealed in the literature. 
The relationship between fraction transpirable of soil water (FTSW) and normalized transpiration rate (NTR) are comparable to that fund for many species [13] [33] and consistent with the general description of leaves transpiration in response to water stress. The equation of [21] proposed to descript the evolution of leave transpiration in response to FTSW well adjusted our data (Figure 3).

\subsection{Seedlings Growth and Their Responses to Progressive Soil Drying}

Seedlings growth of the six accessions was similar during the first 3 months of sowing. Therefore, in the base of the growth parameters measured, it will be difficult to identify accessions presenting the best growth during the first 3 months after sowing. [11] reported that accessions of $J$. curcas from different geographic zones (Inde, Thai and Ethiopia) didn't show any difference in their growth during the first 3 months.

Seedling growth in our study was low to that reported by [11] under high concentration of $\mathrm{CO}_{2}$ and where plants were irrigated by water containing a balanced nutrient mixture. However, seedling growth during the 3 to 4 month in our experimentation was better than that reported by [34] after 6 months of growth in India under high temperature and humidity. This highlighted the sensitivity of J. curcas growth to environmental conditions as reported by [1].

Seedling growth of the different accessions has been affected by severe water stress as reported for shrubs species [35]. Seedlings reduced their leaf area by dropping some of its leaves and stopping new leaves emission. The sensitivity of physiological parameters (decreasing in stomatal conductance, transpiration) to water stress might explain the effects of water stress on growth [31]. In case of $J$. curcas, growth is not affected immediately with stopping irrigation. We recorded new leaves one week after water stress imposition (data not showed).

\section{Acknowledgements}

I am grateful to Dr SINE and to M. FABRE for their comments and advices regarding the material and methods. I'm also thankful to Mrs. SAMBAKHE for her help in statistical analysis.

\section{References}

[1] Heller, J. (1996) Physic Nut. Jatropha curcas L. Promoting the Conservation and Use of Underutilized and Neglected Crops. Institute of Plant Genetics and Crop Plant Research Notes, Gatersleben/International Plant Genetic Resources Institute, Rome, 66.

[2] Rao, K., Wani, S., Singh, P., Srinivas, K. and Rao, S. (2012) Water Requirement and Use by Jatropha curcas in a Semi-Arid Tropical Location. Biomass and Bioenergie, 39, 175-181. https://doi.org/10.1016/j.biombioe.2012.01.013

[3] Divakara, B.N., Upadhyaya, H.D., Wani, S.P. and Gowda, C.L. (2009) Biology and Genetic Improvement of Jatropha curcas L.: A Review. Applied Energy, 87, 
732-742. https://doi.org/10.1016/j.apenergy.2009.07.013

[4] Wani, S.P., Osman, M., D’silva, E. and Sreedevi, T.K. (2006) Improved Livelihoods and Environmental Protection through Biodiesel Plantations in Asia. Asian Biotechnology Develop Review, 8, 11-29.

[5] Fairless, D. (2007) The Little Shrub That Could-Maybe. Nature, 449, 652-655. https://doi.org/10.1038/449652a

[6] Achten, W.M.J., Verchot, L., Franken, Y.J., Mathijs, E., Singh, V.P., Aerts, R. and Muys, B. (2008) Jatropha Bio-Diesel Production and Use. Biomass and Bioenergy 35, 1063-1084. https://doi.org/10.1016/j.biombioe.2008.03.003

[7] Dia, D., Sakho-Jimbira, M.S., Fall, C.S., Ndour, A. and Dieye, P.N. (2010) Crise énergétique et recomposition de l'espace agricole au Sénégal: Cultures traditionnelles vs biocarburants? Isra-Bame, rapport d'étude, $52 \mathrm{p}$.

[8] Kheira, A. and Atta, N. (2009) Response of Jatropha curcas L. to Water Deficit: Yield, Water Use Efficiency and Oil Seed Characteristics. Biomass Bioenergy, 33, 1343-1350. https://doi.org/10.1016/j.biombioe.2008.05.015

[9] Nicholson, S.E. (2013) The West African Sahel: A Review of Recent Studies on the Rainfall Regime and Its Interannual Variability. ISRN Meteorology, 2013, 32-35. https://doi.org/10.1155/2013/453521

[10] Masle, J., Gilmore, S.R. and Farquhar, G.D. (2005) The ERECTA Gene Regulates Plant Transpiration Efficiency in Arabidopsis. Nature, 436, 866-870.

https://doi.org/10.1038/nature03835

[11] Maes, W.H., Achten, W.M.J., Reubens, B., Raes, D., Samson, R. and Muys, B. (2009) Plant-Water Relationships and Growth Strategies of Jatropha curcas L. Seedlings under Different Levels of Drought Stress. Journal of Arid Environments, 73, 877-884. https://doi.org/10.1016/j.jaridenv.2009.04.013

[12] Bourou, S. (2012) Étude éco-physiologique du tamarinier (Tamarindus indica L.) en milieu tropical aride. Thèse de Doctorat $(\mathrm{PhD})$, Faculté des Sciences en Bio-Ingénieries, Université de Gand, Belgique.

[13] Belko, N., Zaman-Allah, M., Cisse, N., Diop, N.N., Zombre, G., Ehlers, J.D. and Vadez, V. (2012) Lower Soil Moisture Threshold for Transpiration Decline under Water Deficit Correlates with Lower Canopy Conductance and Higher Transpiration Efficiency in Drought-Tolerant Cowpea. Functional Plant Biology, 39, 306-322. https://doi.org/10.1071/FP11282

[14] Murray, F.W. (1967) On the Computation of Saturation Vapor Pressure. Journal of Applied Meteorology, 6, 203-204. https://doi.org/10.1175/1520-0450(1967)006<0203:OTCOSV >2.0.CO;2

[15] Vadez, V. and Sinclair, T.R. (2001) Leaf Ureide Degradation and the $\mathrm{N}_{2}$ Fixation Tolerance to Water Deficit in Soybean. Journal of Experimental Botany, 52, 153-159.

[16] Sinclair, T.R. (2005) Theoretical Analysis of Soil and Plant Traits Influencing Daily Plant Water Flux on Drying Soils. Agronomy Journal, 97, 1148-1152. https://doi.org/10.2134/agronj2004.0286

[17] Ritchie, J.T. (1981) Water Dynamics in the Soil-Plant-Atmosphere System. Plant and Soil, 58, 81-96. https://doi.org/10.1007/BF02180050

[18] Sinclair, T.R. and Ludlow, M.M. (1986) Influence of Soil Water Supply on the Plant Water Balance of Four Tropical Grain Legumes. Australian Journal of Plant Physiology, 13, 329-341. https://doi.org/10.1071/PP9860329 
[19] Liu, F. and Stutzel (2002) Leaf Expansion, Stomatal Conductance, and Transpiration of Vegetable Amaranth (Amaranthus sp.) in Response to Soil Drying. Journal of the American Society for Horticultural Science, 127, 878-883.

[20] Zaman-Allah, M., Jenkinson, D.M. and Vadez, V. (2011) Chickpea Genotypes Contrasting for Seed Yield under Terminal Drought Stress in the Field Differ for Traits Related to the Control of Water Use. Functional Plant Biology, 38, 270-281. https://doi.org/10.1071/FP10244

[21] Muchow, R.C. and Sinclair, T.R. (1991) Water Deficit Effects on Maize Yields Modeled under Current and Greenhouse Climates. Agronomy Journal, 83, 1052-1059. https://doi.org/10.2134/agronj1991.00021962008300060023x

[22] Diagne, A.L. (2003) Transpiration globale et fonctionnement hydrique unitaire chez Acacia tortilis en conditions de déficit pluviométrique. Science et changements planétaires/Sécheresse, 14, 235-240.

[23] Peng, Y., Jiang, G.M., Liu, X.H., Niu, S.L., Liu, M.Z. and Biswas, D.K. (2007) Photosynthesis, Transpiration and Water Use Efficiency of Four Plant Species with Grazing Intensities in Hunshandak Sandland, China. Journal of Arid Environments, 70, 304-315. https://doi.org/10.1016/j.jaridenv.2007.01.002

[24] Diouf, M. (1996) Etude du fonctionnement hydrique et des réponses à l'aridité des ligneux sahéliens cas de Acacia torstilis (Forssk.) Hayne subsp. Raddiana (Savi) Brenan en zone soudano-sahélienne du Sénégal. Doctorat de $3^{\text {ème }}$ cycle de Biologie végétale, Université Cheikh Anta Diop de Dakar (UCAD), Dakar, 297 p.

[25] Ouattara, B., Ndir, K.N., Gueye, M.C., Diédhiou, I., Barnaud, A., Fonceka, D., Cisse, N., Akpo, E.L. and Diouf, D. (2014) Genetic Diversity of Jatropha curcas L. in Senegal Compared with Exotic Accessions Based on Microsatellite Markers. Genetic Resources Crop Evolution, 61, 1039-1045. https://doi.org/10.1007/s10722-014-0106-5

[26] Rashed, M.R.R. (2016) Substrate Effects on Plant Transpiration Rate under Several Vapour Pressure Deficit (VPD) Levels. Journal of Plant Pathology and Microbiolo$g y, 7,369$. https://doi.org/10.4172/2157-7471.C1.003

[27] Ouattara, B., Diédhiou, I., Ndir, K.N., Agbangba, E.C., Cisse, N., Diouf, D., Akpo, E.L. and Zongo, J.D. (2013) Variation in Seed Traits and Distribution of Jatropha curcas L. in Senegal. International Journal of Current Research, 5, 17-21.

[28] Ndir, et al. (2013) Variability in Seed Traits, Oil Content and Genetic Diversity in Local and Exotic Accessions of Jatropha curcas L. in Senegal. African Journal of Biotechnology, 12, 5267-5277. https://doi.org/10.5897/AJB2013.11939

[29] Kanchanaketu, T., Sangduen, N., Toojinda, T. and Hongtrakul, V. (2012) Genetic Diversity Analysis of Jatropha curcas L. (Euphorbiaceae) Based on Methylation-Sensitive Amplification Polymorphism. Genetics and Molecular Research, 11, 944-955. https://doi.org/10.4238/2012.April.13.2

[30] Mohibbe Azam, M., Waris, A. and Nahar, N.M. (2005) Prospects and Potential of Fatty Acid Methyl Esters of Some Non-Traditional Seed Oils for Use as Biodiesel in India. Biomass \& Bioenergy, 29, 293-302. https://doi.org/10.1016/j.biombioe.2005.05.001

[31] Zhang, X., Wu, N. and Lia, C. (2005) Physiological and Growth Responses of Populus davidiana Ecotypes to Different Soil Water Contents. Journal of Arid Environments, 60, 567-579. https://doi.org/10.1016/j.jaridenv.2004.07.008

[32] Rodriguez, H.G., Silva, I.C., Meza, M.V. and Lozano, R.G. (2004) Plant Water Relations of Thornscrub Shrub Species, North-Eastern Mexico. Journal of Arid Envi- 
ronments, 58, 483-503. https://doi.org/10.1016/j.jaridenv.2003.12.001

[33] Ray, J.D. and Sinclair, T.R. (1997) Stomatal Closure of Maize Hybrids in Response to Soil Drying. Crop Science, 37, 803-807.

https://doi.org/10.2135/cropsci1997.0011183X003700030018x

[34] Ginwal, H.S., Phartyal, S.S., Rawat, P.S. and Srivastava, R.L. (2005) Seed Source Variation in Morphology, Germination and Seedling Growth of Jatropha curcas Linn. in Central India. Silvae Genetica, 54, 76-80. https://doi.org/10.1515/sg-2005-0012

[35] Maatallah, S., Ghanem, M.E., Albouchi, A., Bizid, E. and Lutts, S. (2010) A Greenhouse Investigation of Responses to Different Water Stress Regimes of Laurus nobilis Trees from Two Climatic Regions. Journal of Arid Environments, 74, 327-337. https://doi.org/10.1016/j.jaridenv.2009.09.008 